\title{
Attenuation of Pseudomonas aeruginosa Virulence by Some Indonesian Medicinal Plants Ethanolic Extract
}

\author{
Sylvia Utami Tunjung Pratiwi ${ }^{1,2^{*}}$, Titik Tri Handayani ${ }^{1,2}$
}

\section{Sylvia Utami Tunjung Pratiwi ${ }^{1,2^{*}}$, Titik Tri Handayani ${ }^{1,2}$ \\ 1,2Department of Pharmaceutical Biology, Faculty of Pharmacy, Gadjah Mada University, Sekip Utara, Yogyakarta, INDONESIA. \\ 1,2 Centre for Natural Anti-infective Research (CNAIR), Faculty of Pharmacy, Gadjah Mada University, Sekip Utara, Yogyakarta, INDONESIA. \\ Correspondence \\ Dr. Sylvia Utami Tunjung Pratiwi \\ Department of Pharmaceutical Biology, Faculty of Pharmacy, Gadjah Mada University, Sekip Utara, Yogyakarta, INDONESIA. \\ Phone no : +62 (0)274 543120 \\ E-mail: sylvia_pratiwi@ugm.ac.id History \\ - Submission Date: 20-02-2018; \\ - Review completed: 14-03-2018; \\ - Accepted Date: 28-06-2018}

DOI : 10.5530/pj.2018.5.167

Article Available online http://www.phcogj.com/v10/i5

\section{Copyright}

(C) 2018 Phcog.Net. This is an openaccess article distributed under the terms of the Creative Commons Attribution 4.0 International license.

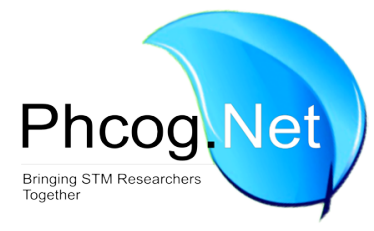

\begin{abstract}
Context: One strategy to address the emergence of infectious diseases supported by the increasing cases of microbial antibiotic resistance is the development of anti-pathogenic drugs, a quorum quenching compound(s) capable of inhibiting microbial communication (quorum sensing inhibitor). Pseudomonas aeruginosa is one of the most common source of chronic opportunistic infections, which demonstrates the most consistent resistance to antimicrobial agents. Quorum sensing (QS) controls secretion of virulence factors in P. aeruginosa. Aim: This study aims to discover quorum sensing inhibitors (QSI) from some Indonesian medicinal plants ethanol extract to analyze their inhibitory activities against QS-mediated virulence factors in P. aeruginosa. Settings and Design: In-vitro experimental study-laboratory setting Materials and Methods: Indonesian medicinal plant ethanolic extracts were tested for their capability to inhibit $P$. aeruginosa motility, biofilm formation using microtiter plate method, pyocyanin and LasA production using LasA staphylolytic assay. Statistical analysis used: Statistical significance of the data were determined using one way ANOVA, followed by Dunnett's test. Differences were considered significant with $P$ values of 0.05 or less. Results: Ethanolic extract of $T$. catappa leaves and $A$. alitilis flower capable to inhibit $P$. aeruginosa motility as well as pyocyanin production and biofilm formation. Both extracts also showed capability in reducing LasA protease production. Conclusion: T. catappa and A. alitilis are an interesting sources of innovative plant derived quorum quenching compound(s), thus can be used in the development of new antipathogenic drug.

Key words: Ethanol extract, Anti-pathogenic drugs, Quorum quenching, Quorum sensing inhibitor, Pseudomonas aeruginosa.
\end{abstract}

\section{INTRODUCTION}

Quorum sensing is a process of cell to cell communication in bacteria mediated by a small diffusible molecule called auto inducers (oligopeptides in Gram positive and $\mathrm{N}$-acyl homoserine lactone (AHL) in Gram negative bacteria). These auto inducers diffuse freely from the bacterial cell and accumulate in the surrounding environment. When a threshold concentration (quorum) has been reached they diffuse back into the cell and regulate transcription of specific genes as in a response to their changing environmental conditions. ${ }^{1}$ Fungi, like bacteria, also use quorum sensing to affect population-level behaviours such as biofilm formation and pathogenesis. ${ }^{2}$

Examples of cellular processes modulated by quorum sensing are biofilm formation, ${ }^{3}$ LasA protease production, pigment production, and motility. ${ }^{4}$ These traits have also shown to be involved in the pathogenicity of bacteria. ${ }^{5}$ It has been suggested that targeting the quorum sensing system by interruption of bacterial communication, instead of killing bacteria, is an example of an antipathogenic effect and may give a solution to antibiotics resistance. ${ }^{6}$ Therefore, anti-quorum sensing

(anti-QS) compounds can be of great interest in the treatment of bacterial infections. ${ }^{7}$

Plants have long been a source of medicines and continues to contribute significantly to the development of today's pharmaceuticals for therapeutics and source of new bioactive compounds. ${ }^{8}$ Indonesia harbours a very high flora of diverse species used in traditional ways as medicine. ${ }^{9}$ Previous anti-infective studies on Indonesian medicinal plants have focused mainly on antimicrobial drug discovery perspectives. However, no systemic effort has been made to explore its anti-QS activity. Furthermore, shifting the focus from antibacterial activity to antiQS properties may disclose new quorum quenching compounds. ${ }^{10}$ For this reason, research in determining anti-QS activity of a compound is generating potential for development of a new therapeutic.

Motility of $P$. aeruginosa in aqueous and dry environments has been shown to be associated with its virulence. In the presence of a quorum sensing inhibitory compound, the motility and therefore the virulence will be limited. ${ }^{11}$ Six different forms of bacterial movement have been described including 
swimming, swarming, twitching, gliding, sliding and darting. ${ }^{12}$ These various forms of surface motility enable bacteria to increase their efficiency of nutrient uptake, avoid toxic substances, move to preferred hosts and provide access to optimal colonization sites within, and spread themselves into the environment. ${ }^{13}$ Bacterial motility plays a different role in biofilms. They can promote adhesion of the cell to the surface for biofilm maturation process and/or in be involved in the dispersal process. ${ }^{14}$ However, motility is not critical to biofilm formation, which was shown for biofilms produced by $P$. aeruginosa PAO1 mutant strain which is lack flagella and type IV pili. ${ }^{15}$

In this study, we provide the screening result of some commonly used Indonesian medicinal plants for anti-QS activity using the $P$. aeruginosa $\mathrm{PAO} 1$ in reducing quorum sensing related motility of $P$. aeruginosa $\mathrm{PAO} 1$ such as swimming, swarming and twitching motility, biofilm formation inhibition, pyocyanin pigment production, and LasA protease production inhibition. We have found potential anti-QS activity in Terminalia catappa leaves and Artocarpus alitilis flower ethanol extracts.

\section{SUBJECTS AND METHODS}

\section{Bacterial isolate and culture conditions}

The bacterial strains used in this study were P. aeruginosa PAO1 and Staphylococcus aureus Cowan I strain. Bacterial strains were grown on Luria-Bertani (LB) Agar and incubated for $24 \mathrm{~h}$ at $30^{\circ} \mathrm{C}$. Following the incubation on agar plate, the colonies were transferred to LB broth and incubated for another $24 \mathrm{~h}$ at $30^{\circ} \mathrm{C}$. Cell density was adjusted to $10^{8} \mathrm{CFU} / \mathrm{mL}$ by altering the optical density of the suspension to 0.1 at $600 \mathrm{~nm}$.

\section{Medicinal plants and plant extraction}

Indonesian medicinal plants were collected from Yogyakarta, Indonesia and its surroundings based on ethnopharmacological information. Plants samples were washed, cut into small pieces and oven dried at $40^{\circ} \mathrm{C}$ for $48-72 \mathrm{~h} .{ }^{16}$ The process of drying prevents degradation through metabolic process, and prevents microbial development. The drying temperature may vary from $35^{\circ} \mathrm{C}$ to $70^{\circ} \mathrm{C}$ depending on the part of the plant and sensitivity of the active principles. For the leaves, a temperature range of $20^{\circ} \mathrm{C}-40^{\circ} \mathrm{C}$ is recommended. Drying plant material in oven with low drying temperatures between $30^{\circ} \mathrm{C}$ and $50^{\circ} \mathrm{C}$ is faster than exposure plant materials to fresh air (shaded from direct sunlight), and still capable to protect sensitive active ingredients. ${ }^{17}$ The dried plant materials were ground into a fine powder. The pulverized materials were extracted by maceration using 70\% ethanol in a ratio of $1 \mathrm{~g}$ (plant material): $10 \mathrm{~mL}$ to obtain crude ethanol extract. Furthermore, extracts were dried and concentrated under reduced pressure using a rotary evaporator. Stock solutions $(100 \mathrm{mg} / \mathrm{mL})$ of crude ethanol extract in dimethyl sulfoxide (DMSO) were prepared, filter-sterilized $(0.2 \mu \mathrm{m})$ and stored at $4^{\circ} \mathrm{C}$.

\section{Determination of planktonic minimum inhibitory concentration (PMIC) of plant oils}

MIC values for different plant extracts against $P$. aeruginosa were determined by Micro broth dilution method as followed by Khan et al. ${ }^{18}$ Different concentrations within the range of $0.06 \mathrm{mg} / \mathrm{mL}-1 \mathrm{mg} / \mathrm{mL}$ were tested. The concentration at which the extract depleted the growth of bacterial by at least $50 \%$ was labelled as the PMIC $_{50}$ and was taken to assess the anti QS activity.

\section{Effect of Plant Extracts on Biofilm Formation}

Biofilms were formed on polystyrene flat bottom 96-well microtiter plates (IWAKI). To determine biofilm formation inhibition, extracts at sub inhibitory concentration (concentration of $\mathrm{PMIC}_{50}$ and under) ranging from $0.06-0.5 \mathrm{mg} / \mathrm{mL}$ were used to ensure a concentration that is not affecting the microbial growth. Negative controls (cells + media:
LB medium for $P$. aeruginosa PAO1), positive control (cells + media + chloramphenicol), vehicle controls (cells + media + DMSO), and media controls were included. For the positive controls concentrations of $1 \mathrm{mg} / \mathrm{mL}$ chloramphenicol was used, prepared by serial dilution techniques. Blanks undergo the same treatment as samples, but without incubation. All tests were performed in triplicate.

Plates were incubated for $24 \mathrm{~h}$ at $28^{\circ} \mathrm{C}$. After $24 \mathrm{~h}$ incubation, the content of the well was aspired, rinsed 3 times with distilled water, and dried at room temperature for $10 \mathrm{~min}$. Then, $125 \mu \mathrm{L}$ of $1 \%$ crystal violet stain was added to the wells for staining for $15 \mathrm{~min}$. The excess stain was rinsed off with tap water and $200 \mu \mathrm{L}$ methanol was added to the wells and transferred to a flat-bottom 96-well plates. Optical density readings were obtained by a plate reader at $600 \mathrm{~nm}$. Biofilm formation inhibition was calculated as \% of inhibition by using the formula mentioned below. The $\%$ of inhibition of replicate tests was used to determine the final minimum biofilm inhibitory concentration (MBIC) values. The concentration at which the extract depleted the bacterial biofilm by at least $50 \%$ was labelled as the $\mathrm{MBIC}_{50}$.

$$
\% \text { inhibition }=\left(1-\left(\frac{\overline{\mathrm{x}} \text { ODt }-\overline{\mathrm{x}} \text { ODmc }}{(\overline{\mathrm{x}} \text { ODvc }}\right)\right) \times 100
$$

ODt= optical density $(595 \mathrm{~nm})$ of the test well; ODmc: optical density $(595 \mathrm{~nm})$ of the media control well; ODvc: optical density $(595 \mathrm{~nm})$ of the vehicle control well. ${ }^{19}$

\section{Pseudomonas aeruginosa PAO1 motility test}

The plant ethanol extract and essential oils which inhibited violacein production were further tested to explore their effects on quorum sensing related swarming, swimming and twitching motility of $P$. aeruginosa PAO1. Swimming, swarming and twitching motility assays were performed by the method of Rashid and Kornberg. ${ }^{13}$ Briefly, LB agar $(0.3 \%)$ plates (for swimming motility), and LB agar (0.5\%) plates (for swarming motility) containing sub-inhibitory concentrations of ethanol extract or essential oils were prepared and allowed to dry for $3-4 \mathrm{~h}$ at $30^{\circ} \mathrm{C}$. Plates were point inoculated with freshly grown culture cells using a blunt ended sterile toothpick. For twitching motility, LB agar (1\%) plates were used bacterial cells were inoculated by using a sharp end toothpick and stabbing through the agar to the bottom of the petri dish. After $24 \mathrm{~h}$ of incubation in upright position at $30^{\circ} \mathrm{C}$, the extent of motility was determined by measuring the diameter of the bacterial colony.

\section{Las A staphylolytic assay}

Las-A protease activity was determined by measuring the ability of culture supernatants to lyse boiled S. aureus cells. A $100 \mu \mathrm{L}$ aliquot of $P$. aeruginosa $\mathrm{LB}$ culture supernatant with or without plant extracts added to $900 \mu \mathrm{l}$ of boiled $S$. aureus suspension. OD600 was determined after $0,5,10,15,20,25$, and $30 \mathrm{~min}$. Activity was expressed by measuring OD600 value.

\section{Pyocyanin inhibition assay.}

Pyocyanin was extracted from $P$. aeruginosa culture supernatant and measured by the method as described by Raoof and Latif. ${ }^{20}$ Briefly, a 5 -ml sample of culture grown for $72 \mathrm{~h}$, in LB medium containing plant extract tested, was centrifuged, and the supernatant extracted with $3 \mathrm{ml}$ of chloroform and then re-extracted into $1 \mathrm{~mL}$ of $0.2 \mathrm{~mol} / \mathrm{L} \mathrm{HCl}$ to give a pink to deep red solution. The absorbance of this solution was measured at $520 \mathrm{~nm}$. Concentrations expressed as pyocyanin produced in $1 \mathrm{~g} / \mathrm{mL}$ of culture supernatant were determined by multiplying the optical density at $520 \mathrm{~nm}$ (OD520) by 17.072 . 


\section{Statistical methods}

The data were initially analysed by a normal distribution using the one-sample Kolmogorov-Smirnov test. Following the confirmation of normal distribution, statistical significance of the data was determined using one-way ANOVA, followed by Dunnett's test. Differences were considered significant with $P$ values of 0.05 or less.

\section{RESULT}

\section{Effects of plant ethanol extracts on planktonic growth and biofilm formation of $P$. aeruginosa PAO1.}

The maximum plant extract concentration of $1 \mathrm{mg} / \mathrm{mL}$ of plant ethanol extracts for testing was chosen based on the previous study by Rios and Recio $^{21}$ who reported that extracts should be avoided exhibiting minimum inhibitory concentration (MIC) values higher than $1 \mathrm{mg} / \mathrm{mL}$ or isolated compounds exhibiting MIC values higher than $0.1 \mathrm{mg} / \mathrm{mL}$. The inoculums concentration used in this study is $10^{5} \mathrm{CFU} / \mathrm{mL}$. According to Clinical and Laboratory Standards Institute (CLSI) guidelines, ${ }^{22}$ a $5 \times 10^{5} \mathrm{CFU} / \mathrm{mL}$ inoculum provides an acceptable challenge dose for assessing the biological activity of anti-microbial agents and is large enough to provide statistically satisfactory data. If the inoculum is too small, significant bacteria resistance may not be detected. As demonstrated by Barry et al. ${ }^{23}$ the growth phase may not have significant effect on MIC determination assay, however, it does critical in the MBC assay because if a stationary phase of inoculums is used, the number of surviving cells tends to increase after $24 \mathrm{~h}$ incubation and makes the $\mathrm{MBC}$ result artificially high.

The percentage of planktonic growth inhibition was measured from the reduction in absorbance level of the treatments wells which is indirectly measure the bacterial cells biomass, compare to negative control well (without the presence of the test compounds). The negative control was assumed to have $0 \%$ activity compare to the compounds tested. Extract concentration around $\mathrm{PMIC}_{50}$ and below (sub-PMIC) were used for further tests, to ensure a concentration that is not affecting the microbial growth.

As shown in Table 1, most of the crude extracts used in this study have anti-bacterial activity against planktonic growth of $P$. aeruginosa PAO1 except ethanol extract of languas rhizome, A. alitilis fruit and A. muricata leaves.

In addition to testing of the plant extracts for inhibition of planktonic growth we also have investigated their effect on biofilm formation. Crystal violet staining has been widely adopted by microbiologist to investigate biofilm formation and attachment of microorganisms to diverse surfaces. This staining method is inexpensive, relatively quick, and adaptable for use in high-throughput screening with microliter plates. ${ }^{24}$

Using the crystal violet method, we have found that the inhibition of biofilm formation was dose dependent in P. aeruginosa PAO1. Plant ethanol extract concentration of $0.5 \mathrm{mg} / \mathrm{mL}$ is the lowest concentration which shows $50 \%$ inhibition on $P$. aeruginosa biofilm formation (Table 1 ). Three extracts i.e. A. alitilis flower, $M$. indica leaves and T. catappa leaves, tested inhibit $50 \%$ of $P$. aeruginosa PAO1 biofilm formation at concentration of $0.5 \mathrm{mg} / \mathrm{mL}$.

\section{Inhibition of bacterial motility}

We investigated if the extracts which inhibited quorum sensing had any effect on quorum sensing related motility in the human opportunistic pathogen $P$. aeruginosa PAO1. Our result, shown in Table 2, indicated that ethanol extracts of A. alitilis flower and T. catappa leaves at a concentration of $0.5 \mathrm{mg} / \mathrm{mL}$ significantly reduced the swimming motility of $P$. aeruginosa PAO1 by $47.38 \pm 0.76 \%(P<0.005)$ and $74.68 \pm 0.86 \%$

\begin{tabular}{|c|c|c|c|c|}
\hline Plant extract & $\begin{array}{l}\text { Local } \\
\text { name }\end{array}$ & $\begin{array}{c}\text { Plant } \\
\text { part }\end{array}$ & $\begin{array}{c}\text { Planktonic } \\
\text { antibacterial } \\
\text { activitivy }\left(\mathrm{PMIC}_{50} \text { ) }\right. \\
\text { in } \mathrm{mg} / \mathrm{mL}^{*}\end{array}$ & $\begin{array}{c}\text { Antibiofilm } \\
\text { formation } \\
\text { activity } \\
\left(\mathrm{MBIC}_{50}\right) \text { in } \\
\mathrm{mg} / \mathrm{mL}^{*}\end{array}$ \\
\hline Languas galanga & Laos & Rhizome & 0.5 & - \\
\hline Centella asiatica & Pegagan & Leaves & 0.5 & 1 \\
\hline \multirow[t]{2}{*}{ Artocarpus alitilis } & Sukun & Flower & 1 & 0.5 \\
\hline & & Fruit & - & - \\
\hline $\begin{array}{l}\text { Andrographis } \\
\text { paniculata }\end{array}$ & Sambiloto & Leaves & 1 & 1 \\
\hline Annona muricata & Sirsak & Leaves & - & - \\
\hline $\begin{array}{l}\text { Muntingia } \\
\text { calabura }\end{array}$ & $\begin{array}{c}\text { Talok } \\
\text { (Kersen) }\end{array}$ & Leaves & - & 1 \\
\hline Mangifera indica & Mangga & Leaves & 1 & 0.5 \\
\hline Terminalia catappa & Ketapang & Leaves & - & 0.5 \\
\hline
\end{tabular}

Table 2: Antimotility efficacy of some medicinal plants ethanol extract against $P$. aeruginosa.

\begin{tabular}{cccccc}
\hline Plant & Part & $\begin{array}{c}\text { Concentration } \\
(\mathrm{mg} / \mathrm{mL})\end{array}$ & \multicolumn{3}{c}{ Motility $(\mathrm{mm})$} \\
\cline { 4 - 6 } & & 1 & $54.37 \pm 0.57$ & $52.42 \pm 0.28$ & $46.72 \pm 0.00$ \\
\hline C. asiatica & Leaves & & Swimming & Swarming & Twitching \\
A. alitilis & Flower & 0.5 & $47.38 \pm 0.76$ & $56.81 \pm 0.28$ & $62.09 \pm 0.28$ \\
& Fruit & 1 & $29.57 \pm 0.57$ & $47.00 \pm 0.76$ & $44.75 \pm 0.00$ \\
A. paniculata & Leaves & 1 & $44.37 \pm 0.76$ & $51.40 \pm 0.00$ & $52.87 \pm 0.57$ \\
A. muricata & Leaves & 1 & $27.39 \pm 0.57$ & $40.25 \pm 0.76$ & $38.76 \pm 0.57$ \\
M. calabura & Leaves & 1 & $33.52 \pm 0.42$ & $60.47 \pm 0.28$ & $62.35 \pm 0.42$ \\
M. indica & Leaves & 0.5 & $42.65 \pm 0.00$ & $33.56 \pm 0.57$ & $48.05 \pm 0.57$ \\
T. catappa & Leaves & 0.5 & $74.68 \pm 0.86$ & $67.80 \pm 0.28$ & $75.80 \pm 0.00$ \\
\hline
\end{tabular}

$(p<0.005)$, respectively. The swarming motility of $P$. aeruginosa PAO1 was also reduced as much as $56.81 \pm 0.28 \%(p<0.005)$ and $67.8 \pm 0.28 \%$ $(p<0.005)$ when extracts at concentrations of $0.5 \mathrm{mg} / \mathrm{mL}$ were applied. The same concentrations of the extract also showed a decrease in twitching motility namely, $62.09 \pm 0.28 \%(p<0.005)$ and $75.8 \pm 0.00 \%(p<0.005)$ respectively.

\section{Pyocyanin inhibition assay}

We tested the effect of plant extracts on pyocyanin pigment production in $P$. aeruginosa. Our result suggest that $T$. catappa leaves ethanol extract showed inhibition of pyocyanin pigment formation by $63.41 \pm 0.6 \%$ $(p<0.005)$ (Figure 1), whereas at the same concentration A. alitilis flower ethanol extract showed inhibition of $63.41 \pm 0.6 \%(p<0.005)$ (Figure 2$)$, respectively.

\section{LasA Staphylolytic}

Inhibition of LasA protease in P. aeruginosa by plant extracts tested was assessed via LasA staphylolytic assay. T. catappa leaves ethanol extract exhibited inhibition of LasA protease production by $73.2 \pm 0.6 \%(p<0.005)$, whereas at the same concentration A. alitilis flower ethanol extract showed inhibition of $70.6 \pm 0.8 \%(p<0.005)$ (Figure 3$)$, respectively. 


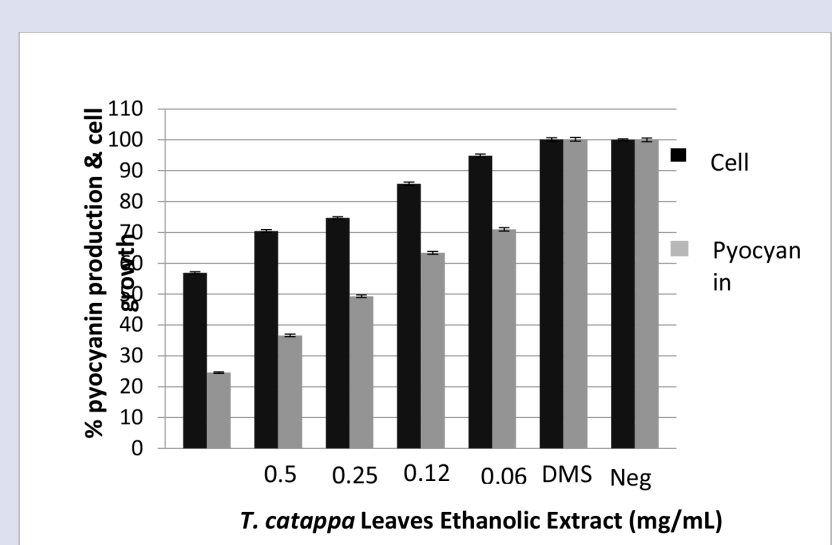

Figure 1: Efficacy of T. catappa flower ethanol extracts in various concentration against pyocanin production in P. aeruginosa. $0.3 \% \mathrm{v} / \mathrm{v}$ DMSO was used as vehicle control.

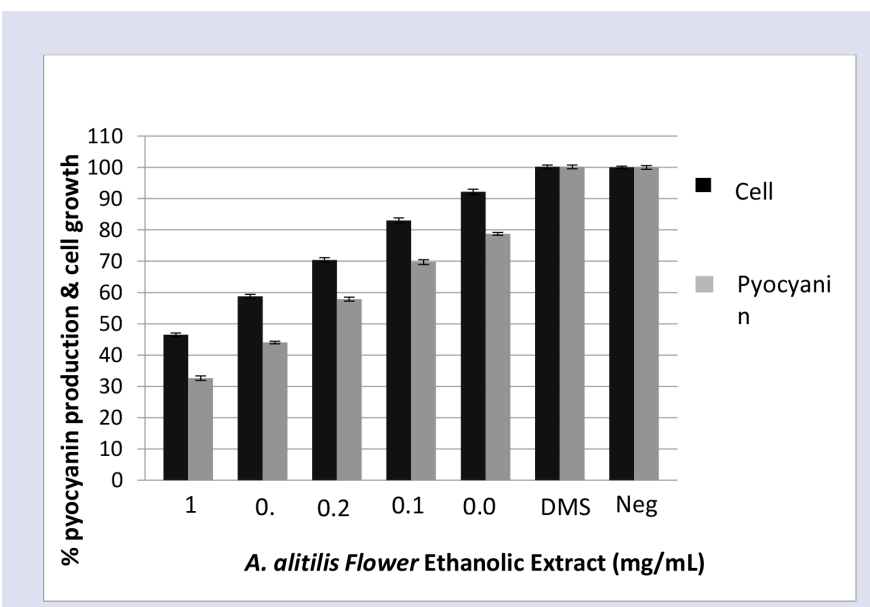

Figure 2: Efficacy of $A$. alitilis flower ethanol extracts in various concentration against pyocanin production in P. aeruginosa. $0.3 \% \mathrm{v} / \mathrm{v}$ DMSO was used as vehicle control.

\section{LasA Staphylolytic inhibition}

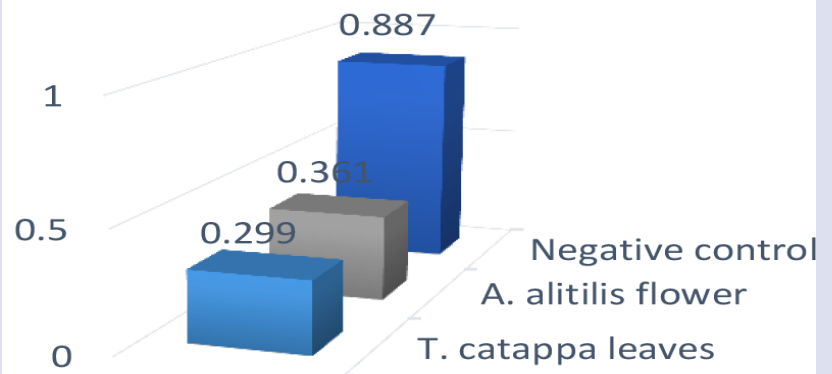

\section{Samples}

Figure 3: LasA protease activity.

\section{DISCUSSION}

The aim of this study was to determine the anti-QS potential of ethanol extracts and essential oils from Indonesian medicinal plants with a potential to a possible use in controlling detrimental infections. Quorum sensing in P. aeruginosa has been well studied. This organism has two QS systems, LasR/I and RhlR/I systems. The lasI produces diffusible extracellular signal, N-(3-oxododecanoyl)-L-homoserine lactone (3-oxo-C12HSL) which binds with LasR to activate a number of virulence genes and biofilm maturation, and to regulate the expression of LasI. In the Rhl system, the RhlI synthase produces N-butyryl-L-homoserine lactone (C4-HSL), which interacts with RhlR protein and activated C4-HSLRhlR complex, further stimulates the expression of RhlI, virulence genes and biofilm associated genes and biofilm associated genes. ${ }^{25}$

P. aeruginosa produces a third signalling molecule, 2-heptyl-3-hydroxy$4(1 \mathrm{H})$-quinolone, called Pseudomonas quinolone signal (PQS). It is produced by the $p q s$ ( $p q s A B C D E$ ) operon and pqsH gene, wherein the pqs $A B C D E$ operon products synthesize 2-heptyl-4-hydroxyquinoline (HHQ), and the PqsH converts HHQ into PQS. PQS diffuses in and out of the cell, accumulates in the environment, and when a threshold concentration reached, it binds to the regulator protein, PqsR, which modulates genes encoding virulence factors and the synthesis of PQS itself, resulting in autoinduction. ${ }^{25}$

There are several reports in literature that propose different mechanisms of quorum sensing inhibition by natural products, either by inhibition of the signal molecule biosynthesis, ${ }^{26}$ preventing the binding of the AHL molecules to its receptors ${ }^{6}$ or enzymatic inactivation and biodegradation of the quorum sensing signalling molecules. ${ }^{27}$

Plants are the sources of varied bioactive metabolites which useful for the development of successful and effective drugs. Various plants have demonstrated the ability to interfere with microbial QS systems that further and control its virulence. Vanilla (Vanilla planifolia), garlic (Allium sativum), weeping bottlebrush (Callistemon viminalis), Zaragoza mangrove (Conocarpus erectus), graceful sandmat (Chamaesyce hypericifolia), black olive (Bucida buceras), Florida clover ash (Tetrazygia bicolour), and southern live oak (Quercus virginiana), showed quorum sensing inhibitory properties against C. violaceum and Agrobacterium tumefaciens. ${ }^{5}$ Study from Zahin et al. ${ }^{13}$ Chong et al. ${ }^{28}$ and Priya et al..$^{29}$ also revealed quorum sensing property of Mangifera indica, Punica granatum, Myristica cinnamomea and Phyllanthus amarus, which showed efficacy in regulating violacein production of $C$. violaceum and inhibiting motility of $P$. aeruginosa. The result in our study have revealed that the ethanol extract of T. catappa leaves and A. alitilis flower significantly inhibit the quorum sensing mechanism of $P$. aeruginosa PAO1 as indicated by a reduction in pyocyanin production, inhibition of $P$. aeruginosa motility, reduction in LasA protease production and inhibition of $P$. aeruginosa biofilm formation which is an important trait for its pathogenicity. It is concluded that anti-QS is as important as antibacterial activity as it will unlikely cause resistance problems as it does not pose selection pressure.

\section{CONCLUSION}

In conclusion, the finding from this study conclusively demonstrated the in vitro antiquorum sensing activity of T. catappa and A. alitilis ethanol extract, makes them as an interesting sources to be used in the development of new antipathogenic drug. Further purification of the active compounds may be suggested on the basis of the present study.

\section{ACKNOWLEDGEMENT}

The research fund from Faculty of Pharmacy Universitas Gadjah Mada, Yogyakarta, Indonesia was gratefully acknowledged. 


\section{CONFLICT OF INTEREST}

The authors declare no conflict of interest.

\section{REFERENCES}

1. Waters CM, Bassler BL. Quorum Sensing: Cell-to Cell Communication in Bacteria. Annu Rev Cell Dev Biol. 2005;21:319-46.

2. Albuquerque P, Casadevall A. Quorum Sensing in Fungi - A Review. Med Mycol. 2012;50(4):337-45

3. McClean KH, Winson MK, Fish L, Taylor A, Chhabra SR, Camara M, et al. Quorum Sensing and Chromobacterium violaceum: Exploitation of Violacein Production for The Detection of N-Acylhomoserine Lactones. Microbiol. 1997; 143(12):3703-11

4. Eberl L, Molin S, Givskov M. Surface Motility of Serratia liquefaciens MG1. J Bacteriol. 1999;181(6):1703-12

5. Choo JH, Rukayadi Y, Hwang JK. Inhibition of Bacterial Quorum Sensing by Vanilla Extract. Lett Appl Microbiol. 2006;42(6):637-41.

6. Hentzer M, Givskov M. Pharmacological Inhibition of Quorum Sensing for The Treatment of Chronic Bacterial Infections. J Clin Invest. 2003;112(9):1300-7.

7. Rice SA, Mc Dougald D, Kumar N, Kjelleberg S. The Use of Quorum Sensing Blockers as Therapeutic Agents for the Control of Biofilm Associated Infections. Curr Opin Investig Drugs. 2005;6(2)178-84.

8. Cragg GM, Newman DJ, Snader KM. Natural Products in Drug Discovery and Development. J Nat Prod. 1997;60(1):52-60.

9. Damayanti EK, Hikmat A, Zuhud EA. Indonesia Tropical Medicinal Plants Diversity: Problems and Challenges in Identification, International Workshop "Linking Biodiversity and Computer Vision Technology to Enhance Sustainable Utilization of Indonesian Tropical Medicinal Plants", Bogor, Indonesia. 2011;11. Available online: http://damayantiellyn.files.wordpress.com/2011/08/2011 intlworkshop_ medplantspaper.pdf, Access date: 15 October 2017.

10. Adonizio AL, Downum K, Benett BC, Mathee K. Anti-quorum Sensing Activity of Medicinal Plants in Southern Florida. J Eth Pharmacol. 2006;105(3):427-35

11. Majik MS, Naika D, Bhatb C, Tilveb S, Tilvia S, D'Souza L. Synthesis of (R)-Norbgugaine and Its Potential as Quorum Sensing Inhibitor Against Pseudomonas aeruginosa. Bioorg Med Chem Lett. 2013;23(8):2353-6.

12. Hentzer M, Givskov M. Pharmacological Inhibition of Quorum Sensing for the Treatment of Chronic Bacterial Infections. J Clin Invest. 2003;112(9):1300-7.

13. Rashid MH, Kornberg A. Inorganic Phosphate is needed for Swimming, Swarming, and Twitching Motilities of Pseudomonas aeruginosa. Proceedings of the National Academy of Sciences of the United States of America (PNAS) 2000:97(9):4885-90.

14. Marchal M, Briandet R, Koecchler S, Kammerer B, Bertin PN. Effect of Arsenite on Swimming Motility Delays Surface Colonization in Herminiimonas arsenicoxydans.
Microbiol. 2010;156(8):2336-42

15. Chow S, Gu K, Jiang L, Nassour A. Salicylic Acid Affects Swimming, Twitching and Swarming Motility in Pseudomonas aeruginosa, Resulting in Decreased Biofilm Formation. Journal of Experimental Microbiology and Immunology (JEMI). 2011;15:22-9.

16. Salie F, Eagles PF, Leng HM. Preliminary Anti-microbial Screening of Four South African Asteraceae Species. J Ethnopharmacol. 1996;52(1):27-33.

17. Cechinel FV. Plant Bioactives and Drug Discovery: Principles, Practise and Perspective. John Wiley and Sons. Inc Hoboken NJ USA. 2002;364-73.

18. Khan MS, Zahin M, Hasan S, Husain FM, Ahmad I. Inhibition of Quorum Sensing Regulated Bacterial Functions by Plant Essential Oils with Special Reference to Clove Oil. Lett Applied Microbiol. 2009;49(3):354-60

19. Quave CL, Plano LR, Pantuso T, Benett BC. Effects of Extracts from Italian Medicinal Plants on Planktonic Growth, Biofilm Formation and Andher ence of Methicillin-Resistant Staphylococcus aureus. J Ethnopharmacol. 2008;118(3):418-28

20. Ra' oof WM, Latif IA. In vitro Study of The Swarming Phenomena and Antimicrobial Activity of Pyocyanin Produced by Pseudomonas Aeruginosa Isolated from Different Human Infections. Eur J Sci Res. 2010;47(3):405-21.

21. Rios JL, Recio MC. Medicinal Plants and Anti-Microbial Activity. J Ethnopharmacol. 2005;100(1-2):80-4

22. Clinical and Laboratory Standard Institute (CLSI). Performance Standards for Anti-microbial Susceptibility Testing: Seventeenth Informational Supplement. Clinical and Laboratory Standards Institute (CLSI) Document M100-S17, (ISBN 1-56238-625-5). Clinical and Laboratory Standard Institute, Wayne, Pennsylvania USA. 2007.

23. Barry AL, Badal RE, Hawkinson RW. Influence of inoculum growth phase on microdilution susceptibility tests. J Clin Microbiol. 1983;18(3):645-51.

24. Niu C, Gilbert ES. Colorimetric Method for Identifying Plant Essential Oi Components That Affect Biofilm Formation and Structure. Appl Environ Microbiol. 2004;70(12):6951-6

25. Desai K, Gala V. Plant Based Quorum Sensing Inhibitors of Pseudomonas aeruginosa. International Journal of Pharmacy and Pharmaceutical Sciences (IJPPS). 2014;6(8):20-5.

26. Vattem DA, Mihalik K, Crixell SH, McLean R. Dietary Phytochemicals as Quorum Sensing Inhibitors. Fitoterapia. 2007;78(4):302-10

27. Defoirdt T, Boon N, Dossier P, Verstraete W. Disruption of Bacterial Quorum Sensing: An Unexplored Strategy to Fight Infections in Aquaculture. Aquaculture. 2004;240(1-4):69-88.

28. Chong YM, Yin WF, Ho CY, Mustafa MR, Hadi AH, Awang K. Malabaricone C from Myristica cinnamomea exhibits anti-quorum sensing activity. J Nat Prod. 2011;74(10):2261-4.

29. Priya K, Yin WF, Chan KG. Anti-quorum Sensing Activity of The Traditional Chinese Herb, Phyllanthus amarus. J Sensors. 2013;13(11):14558-69.

\section{GRAPHICAL ABSTRACT}

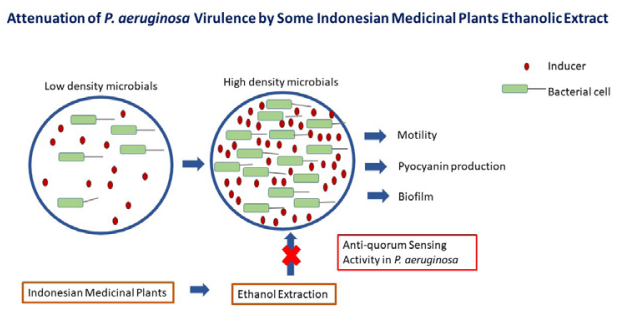

\section{SUMMARY}

- Quorum sensing is a process of cell to cell communication in bacteria mediated by a small diffusible molecule called auto inducers. Quorum sensing regulate bacterial cell activities in order to be able to survive in the environment. Among the many activities controlled by quorum sensing is the expression of virulence factors by pathogenic bacteria. Targeting the quorum sensing system by interruption of bacterial communication, instead of killing bacteria, is an example of an antipathogenic effect and it may also give a solution to the emergence of bacterial resistance to current antibiotics. This research aimed to evaluate anti-OS activity of some Indonesian medicinal plants ethanol extract against QS-mediated virulence factors in $P$. aeruginosa. Our result showed that ethanolic extract of $T$. catappa leaves and $A$. alitilis flower capable to inhibit $P$. aeruginosa motility as well as pyocyanin production and biofilm formation. Both extracts also showed capability in reducing LasA protease production. We conclude that the ethanol extract from T. catappa leaves and A.alitilis flower are an interesting sources of innovative plant derived anti-quorum sensing agents, thus can be used in the development of new antipathogenic drug.

\section{ABOUT AUTHORS}

Sylvia Utami Tunjung Pratiwi is a lecturer at Dept. of Pharmaceutical Biology, Faculty of Pharmacy, Gadjah Mada University. Her research focused on biofilm, antimicrobial resistance and finding novel compound(s) with antipathogenicity activity or high activity against biofilm

Titik Tri Handayani is a laboratory staff at microbiology Laboratory, Dept. of Pharmaceutical Biology, Faculty of

Pharmacy, Gadjah Mada University.

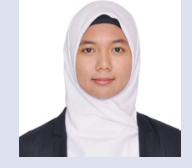

Cite this article: Pratiwi SUT, Handayani TT. Attenuation of Pseudomonas aeruginosa Virulence by Some Indonesian Medicinal Plants Ethanolic Extract. Pharmacog J. 2018;10(5):983-7. 